\title{
Strategies for case management in transitional care in emergency services: scoping review
}

\author{
Estratégias para o gerenciamento de casos no cuidado transicional em serviços de emergência: scoping review \\ Estratégia para el manejo de casos em la atención de transición em servicios de emergência: scoping review
}

Priscilla Gonçalves de Castro Gomes Braz' ORCID: 0000-0003-1124-5401

Vanessa da Silva Carvalho Vila' ORCID: 0000-0002-1785-8682

Heliny Carneiro Cunha Neves" ORCID: 0000-0001-8240-1059

'Pontifícia Universidade Católica de Goiás. Goiânia, Goiás, Brazil. "Universidade Federal de Goiás. Goiânia, Goiás, Brazil.

How to cite this article: Braz PGCG, Vila VSC, Neves HCC. Strategies for case management in transitional care in emergency services: scoping review. Rev Bras Enferm. 2020;73(Suppl 5):e20190506. doi: http://dx.doi.org/10.1590/0034-7167-2019-0506

\section{Corresponding author:}

Priscilla Gonçalves de Castro Gomes Braz E-mail: priscillagoncalves_enf@yahoo.com.br

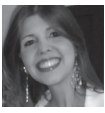

EDITOR IN CHIEF: Dulce Barbosa ASSOCIATE EDITOR: Andrea Bernardes

Submission: 09-23-2019

Approval: 06-14-2020

\section{ABSTRACT}

Objective: to map and synthesize the strategies implemented for case management in transitional care for patients with complex needs in emergency services. Method: a scoping review conducted under the Joanna Briggs Institute guidance. Twenty-three studies were analyzed, with different methodological designs, on the strategies used in case management involving adult and elderly populations in emergency services. Results: the main strategies employed were patient risk stratification screening/identification, care management plan, coordination of care through multidisciplinary activities, support for the transition process, continuous patient monitoring, and follow-up. Final considerations: these strategies used structured approaches to care in emergency services to promote support for self-management and effective transitional care for people with complex needs, ensuring comprehensiveness, coordination, and continuity of care.

Descriptors: Case Management; Patient-Centered Care; Transitional Care; Review; Emergency Medical Services.

\section{RESUMO}

Objetivo: mapear e sintetizar as estratégias implementadas para o gerenciamento de caso no cuidado transicional de pacientes com necessidades complexas nos serviços de emergência. Método: scoping review conduzido segundo os pressupostos metodológicos do Instituto Joanna Briggs. Foram analisados 23 estudos, com diferentes delineamentos metodológicos, sobre as estratégias empregadas no gerenciamento de casos envolvendo populações adultas e idosas, no contexto dos serviços de emergência. Resultados: as principais estratégias empregadas foram: rastreamento/identificação e estratificação de risco do paciente; plano de gerenciamento do cuidado; coordenação do cuidado por meio da atuação multiprofissional; apoio ao processo de transição; monitoramento e seguimento contínuo do paciente. Considerações finais: essas estratégias utilizaram abordagens estruturadas do cuidado nos serviços de emergência, para promover o apoio ao autogerenciamento e o efetivo cuidado transicional de pessoas com necessidades complexas, garantindo a integralidade, coordenação e continuidade do cuidado.

Descritores: Administração de Caso; Assistência Centrada no Paciente; Cuidado Transicional; Revisão; Serviços Médicos de Emergência.

\section{RESUMEN}

Objetivo: mapear y sintetizar las estrategias implementadas para el manejo de casos en la atención de transición de pacientes con necesidades complejas en los servicios de emergencia. Método: una scoping review realizada según los supuestos metodológicos del Instituto Joanna Briggs y de Levac, Colquhoun y O'Brien. Se analizaron 23 estudios, con diferentes diseños metodológicos, sobre las estrategias utilizadas en el manejo de casos en poblaciones de adultos y ancianos, en el contexto de los servicios de emergencia. Resultados: las principales estrategias empleadas fueron: seguimiento/identificación del paciente y estratificación del riesgo; plan de gestión de la atención; coordinación de la atención a través de actividades multiprofesionales; apoyo para el proceso de transición; monitoreo continuo y seguimiento del paciente. Consideraciones finales: estas estrategias utilizaron enfoques de atención estructurada en los servicios de emergencia, para promover el apoyo para el autocontrol y la atención de transición efectiva para las personas con necesidades complejas, asegurando la integralidad, coordinación y continuidad de la atención.

Descriptores: Manejo de Caso; Atencion Dirigida al Paciente; Cuidado de Transicion; Revision Servicios Médicos de Urgência. 


\section{INTRODUCTION}

Studies show that health system users demand care transitions resulting from acute and chronic aggravated conditions ${ }^{(1-2)}$. In general, these individuals experience a combination of complexneeds, resulting from coping with multimorbidity, mental health problems, and social vulnerability, which result in a pattern of extreme use of emergency services, with frequent and unnecessary hospitalizations ${ }^{(3-12)}$.

Despite the growing number of people with complex care and social needs, health care models that focus on illness in health systems still prevail. The complex relationship of social determinants and emotional, psychological, and behavioral factors, which lead to the need to integrate different services to promote continuity of care, is disregarded ${ }^{(13-14)}$.

Care transition consists of a set of actions to ensure the coordination and continuity of care for patients and promote a safe and timely transfer from one level of attention to another ${ }^{(2,15)}$. Transitional care approach is related to a comprehensive care plan; communication; safe use of medications; patient and family education to promote self-management; social and community support; participation of the multidisciplinary team to meet the complex care needs of patients; coordination of care; monitoring and follow-up ${ }^{(16-17)}$.

It is essential to qualify care transition, especially in emergency services, to guarantee and improve patient follow-up after discharge, especially in primary care, and to avoid avoidable future readmissions $^{(18)}$. However, despite the advances in this theoretical conception, both developed and developing countries find, in practice, weaknesses in managing care transition in emergency services ${ }^{(6,19-22)}$.

The main concern of emergency services is the entry of patients, and gaps related to transitions of care ${ }^{(19)}$. Another important aspect refers to the high demand for care and the high costs of these services since a group of users frequently seeks care in these places on several occasions and for different reasons $s^{(6,19,20,23)}$.

Qualifying care transition requires that managers, health professionals, and researchers are effectively engaged in the ongoing debate to search for resolutive strategies that allow them to deal and adequately manage this complex reality ${ }^{(19)}$.

One of the recommended strategies to improve care transition, case management, has shown promising results in terms of qualifying care, promoting quality of life, reducing unnecessary hospitalizations, and, consequently, health care costs ${ }^{(24-26)}$.

The ideal case management model is a collaborative process that involves planning, advocating, facilitating, coordinating care, monitoring, and assessing services according to clients' health needs ${ }^{(27-28)}$. It is made possible through communication between the various members of the multidisciplinary team to meet the health needs of patients and promote effective results concerning the quality of care and health $\operatorname{costs}{ }^{(26,28)}$.

Despite being an internationally consolidated action, in countries like Canada ${ }^{(20,23,29)}$, United States ${ }^{(5,29-31)}$, Australia( ${ }^{(8)}$, Switzerland ${ }^{(32)}$, Sweden ${ }^{(33)}$, and England ${ }^{(12)}$, there is a scarcity of studies that show the importance of case management in care transitions from emergency services to other levels of health care.

In an initial search at MEDLINE via PUBMED to carry out the study, some reviews on emergency services have been identified ${ }^{(6,20,23,34)}$. The studies highlighted the following benefits attributed to case management: promotion of transitional, continuous, and person-centered care; efficacy and effectiveness when applied to various groups in different configurations; and ability to reduce $\operatorname{costs}^{(25,34)}$. The researchers identified the need to synthesize and deepen the description of the characteristics of these strategies; thus, they mentioned the emergency service guidelines, although it was not the primary objective of the reviews present the strategies used for case management ${ }^{(6,20,23)}$.

In this context, this scoping review aimed to identify the strategies used for case management in emergency services by synthesizing evidence from studies with different methodological designs.

This study can contribute to support clinical practice and present new possibilities that allow implementing case management to favor timely, safe, and equitable access to people, families, and communities.

\section{OBJECTIVE}

To map and synthesize the strategies used for case management in transitional care for patients with complex needs in emergency services.

\section{METHODS}

The scoping review developed according to the Joanna Briggs Institute (JBI) methodological assumptions ${ }^{(35)}$, in line with Levac, Colquhoun, and $\mathrm{O}^{\prime}$ Brien recommendations ${ }^{(36)}$. It followed the PRISMA extension checklist for scoping review (PRISMA-SCR) ${ }^{(37)}$. The five methodological were: (1) research question identification; (2) relevant study identification; (3) study selection; (4) result mapping and gathering; and (5) narrative synthesis of the results ${ }^{(35-36)}$.

The guiding question defined through PCC strategy (P - Population; C - Concept; and C - Context) was: what are the strategies for managing cases in the transitional care of patients with complex needs in emergency services? The investigated context involved serving frequent users of emergency services, with a history of multimorbidity, frequent hospitalizations, impaired mental health, and experiencing situations of social vulnerability ${ }^{(3,14)}$.

Chart 1 described the eligibility criteria for the studies.

Chart 1 - Synthesis of eligibility criteria for scoping review

\begin{tabular}{|c|c|}
\hline Inclusion criteria & Exclusion criteria \\
\hline $\begin{array}{l}\text { Participants - adults (18 years old and over) and } \\
\text { older people (over } 60 \text { years old), regardless of } \\
\text { gender, with complex needs. } \\
\text { Concept - strategies for case management in } \\
\text { transitional care. } \\
\text { Context - emergency services } \\
\text { Type of study - quantitative studies (clinical } \\
\text { trials; quasi-experimental studies; prospective } \\
\text { and retrospective observational studies; } \\
\text { analytical case-control and cross-sectional } \\
\text { studies); qualitative studies (descriptive, } \\
\text { phenomenological, ethnographic, action } \\
\text { research and theory based on data); systematic } \\
\text { reviews (with or without meta-analysis) and } \\
\text { meta-syntheses; gray literature (documents and } \\
\text { books published by organizations focused on } \\
\text { case management). }\end{array}$ & $\begin{array}{l}\text { - Not presenting the } \\
\text { descriptive steps of } \\
\text { the strategies for } \\
\text { managing cases in } \\
\text { transitional care. } \\
\text { - Editorials, research } \\
\text { protocols, } \\
\text { comments, theses, } \\
\text { and dissertations. }\end{array}$ \\
\hline
\end{tabular}


We carried out an initial search at MEDLINE (via PUBMED) and CINAHL (via OVID) databases to analyze the keywords contained in titles and abstracts and controlled descriptors used in the studies identified. Based on this analysis, a chart of controlled and uncontrolled descriptors was built. Such chart included key concepts related to patients with complex needs, care transition, case management, and emergency medical services.

A comprehensive and extensive search strategy was adopted to identify studies published until June 2018, in English, Brazilian Portuguese, and Spanish. The research team defined a search strategy for each database, considering the standardized terminology and the following controlled descriptors from Medical Subject Headings (MeSH):"Critical Care", "Continuity Of Patient Care”, "Transitional Care”, "Case Management", and "Emergency Medical Services". A specific search strategy was developed for each database, maintaining combinations of descriptors and using Boolean operators (AND and OR).

The searches were implemented in the following databases: Latin American \& Caribbean Literature and Health Sciences (LILACS); Medical Literature Analysis and Retrieval System Online (MEDLINE) via the US National Library of Medicine Institute of Health (PUBMED); Cumulative Index to Nursing and Allied Health Literature (CINAHL) via OVID; and EMBASE (Excerpta Medica dataBASE) via OVID. There was also access to the Web of Science Core Collection and Google Scholar.

The following steps were taken: 1. specific search in each database; 2 . removal of duplicate articles; 3 . selection by title and abstract; 4 . assessment by reading the full text, discussing discrepancies and agreeing on the final sample; and 5. review of the articles' reference lists in the final sample. All of these steps were carried out independently, by two reviewers, with training in searching scientific information. For this process, the reference manager software Endnote X 7.4 was used.

To ensure methodological rigor, these reviewers participated in weekly meetings so that they could carefully monitor the search and selection process. It is noteworthy that there was no disagreement among them at any stage.

Mapping and gathering the data included a standardized structure ${ }^{(35,36)}$ for recording the following information: author(s); year and country of publication; aims; characteristics of the strategies employed; sample; method; results; and main considerations ${ }^{(35,37)}$.

The narrative synthesis of the results included: (a) numerical synthesis and descriptive abstract; (b) presentation of the characteristics of the case management strategies; (c) synthesis of the results considering the target population and the strategies used for case management in emergency services. The strategies employed were described in terms of the following operational steps $^{(26,28,38)}$ presented in Chart 2.

Chart 2 - Case management process steps

\begin{tabular}{|l|l|}
\hline \multicolumn{1}{|c|}{ Step } & \multicolumn{1}{c|}{ Aim } \\
\hline $\begin{array}{l}1^{\text {st }} \text { step } \\
\text { Risk stratification } \\
\text { screening/ } \\
\text { identification }\end{array}$ & $\begin{array}{l}\text { - To identify (risk stratification) the health situation } \\
\text { (clinical and psychosocial aspects) of patients, } \\
\text { as well as the services required to meet health } \\
\text { needs and that, may affect the progress of care; } \\
\text { assessment of readmission risk; and resources in } \\
\text { the community and potential care partners }\end{array}$ \\
\hline
\end{tabular}

\begin{tabular}{|c|c|}
\hline Step & Aim \\
\hline $\begin{array}{l}2^{\text {nd }} \text { step } \\
\text { Assessment of } \\
\text { patients' needs }\end{array}$ & $\begin{array}{l}\text { - To assess and identify patients' and families' needs: } \\
\text { 1. Health history and medications used; } 2 \text {. Data } \\
\text { on family and caregiver; } 3 \text {. To verify if they have } \\
\text { a family physician or primary care physician; } 4 \text {. } \\
\text { Analysis of hospital clinical records, including past } \\
\text { and current emergency services, auxiliary health } \\
\text { teams, employers; } 5 \text {. Medication in use; } 6 \text {. Other } \\
\text { administrative documents and home care services; } \\
\text { 7. To identify needs for interventions that should be } \\
\text { incorporated into a care plan; } 8 \text {. To determine the } \\
\text { resources needed to address the issues raised }{ }^{(26,28,38)} \text {. }\end{array}$ \\
\hline $\begin{array}{l}3^{\text {rd }} \text { step } \\
\text { Development } \\
\text { of a care } \\
\text { management } \\
\text { plan }\end{array}$ & $\begin{array}{l}\text { - To develop an individualized care plan based on } \\
\text { clinical and psychosocial needs, in collaboration with } \\
\text { the entire team involved in case management, to } \\
\text { ensure the safe transfer of care in the continuum of } \\
\text { care }{ }^{(26,28,38)} \text {. }\end{array}$ \\
\hline $\begin{array}{l}4^{\text {th }} \text { step } \\
\text { Plan } \\
\text { implementation } \\
\text { with care } \\
\text { coordination }\end{array}$ & $\begin{array}{l}\text { - To implement the care plan covering all } \\
\text { interventions necessary to ensure and maintain } \\
\text { the continuity of care for individuals at all levels of } \\
\text { health care }{ }^{(26,28,38)} \text {. }\end{array}$ \\
\hline $\begin{array}{l}5^{\text {th }} \text { step } \\
\text { Care plan } \\
\text { assessment and } \\
\text { follow-up }\end{array}$ & $\begin{array}{l}\text { - To review, follow up, assess, and monitor the } \\
\text { patients' responses to the implemented care plan } \\
\text { as well as monitoring and reassessing the patients' } \\
\text { health conditions }{ }^{(26,28)} \text {. } \\
\text { - To gather information and share it among } \\
\text { professionals; assess the Effectiveness, need for } \\
\text { adjustments in the care plan and its effects on } \\
\text { the patients' health status and recommend new } \\
\text { interventions; verify if patients and family are } \\
\text { satisfied with care and services after discharge } \\
{ }^{(26,28,38)} \text {. }\end{array}$ \\
\hline $\begin{array}{l}6^{\text {th }} \text { step } \\
\text { Support in } \\
\text { the transition } \\
\text { process }\end{array}$ & $\begin{array}{l}\text { - To facilitate the progress of care by advancing } \\
\text { the care plan, aiming to achieve the desired } \\
\text { results and integrating the health care teamwork } \\
\text { to achieve the defined goals; to identify, } \\
\text { communicate, and resolve barriers that thwart the } \\
\text { progress of care; and optimize outcomes across } \\
\text { the continuum of care }{ }^{(38)} \text {. }\end{array}$ \\
\hline $\begin{array}{l}7^{\text {th }} \text { step } \\
\text { Post-transition } \\
\text { communication }\end{array}$ & $\begin{array}{l}\text { - To communicate and share information among } \\
\text { patients, multidisciplinary teams, primary care } \\
\text { providers, and support systems } s^{(26,38)} \text {. } \\
\text { - To verify the care plan implementation: patient } \\
\text { comfort; medication adherence; availability of } \\
\text { post-transition services; requesting feedback on } \\
\text { the experience and satisfaction of patients with } \\
\text { services provided; verification of problems and } \\
\text { search for resolution; and transfer of information } \\
\text { acquired from service providers }{ }^{(28,38)} \text {. }\end{array}$ \\
\hline $\begin{array}{l}8^{\text {th }} \text { step } \\
\text { Periodic } \\
\text { reassessment }\end{array}$ & $\begin{array}{l}\text { - To examine adherence and verify the patients' } \\
\text { responses to the care plan, the need for adjustments; } \\
\text { clarify doubts of patients, families, or caregivers; and } \\
\text { verify patient satisfaction } \\
\text { - To confiris). } \\
\text { determine the need to services after discharge; } \\
\text { readmissions from the emergens to prevent } \\
\text { ensure follow-up in primary care, and complete the } \\
\text { case management process based on patient and } \\
\text { family conditions }{ }^{(28,38)} \text {. }\end{array}$ \\
\hline
\end{tabular}

\section{RESULTS}

After searching the selected databases, assessment and selection of studies were initiated. Of a total of 200 articles initially identified, 161 were excluded for not meeting the pre-established eligibility criteria, and eight were duplicated citations, leaving 
31 publications for a full reading. In this step, 31 articles have been included, based on assessing the reference lists. However, after reading full-text of the 62 articles, 39 were excluded for not explicitly addressing case management in emergency services so that the final sample analyzed corresponded to 23 articles. The results are described in the flowchart shown in Figure 1.

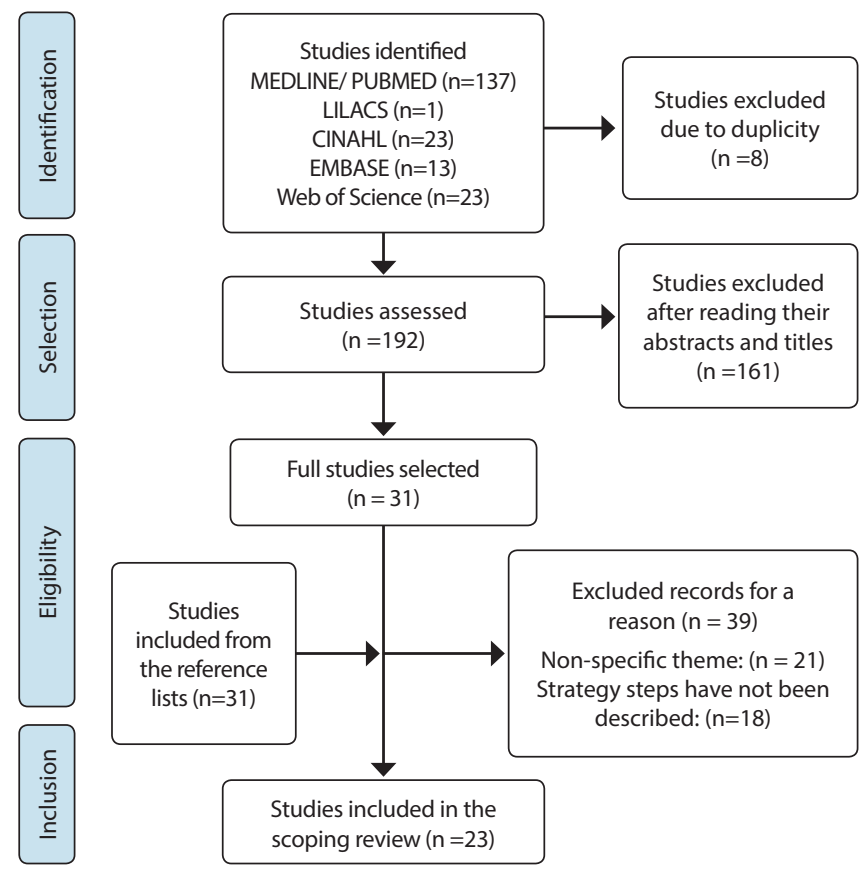

Figure 1 - Flowchart, according to PRISMA, for selection and inclusion of studies in the scoping review ${ }^{(37)}$

Most were published between 2014 and 2018 and conducted in the United States ( 14 articles) and Canada (4 articles). The methodological approaches used were experimental ${ }^{(11,32-33,39)}$, quasi-experimental ${ }^{(7,9,12,40-41)}$, observational ${ }^{(4-5,8,30,42)}$ studies, systematic reviews without meta-analysis ${ }^{(6,20,29)}$, thematic analysis reviews ${ }^{(23)}$, and other modalities (experience reports and reflection articles) ${ }^{(31,43-46)}$ (Chart 3).

Chart 3 - Selected studies in the scoping review on case management strategies in emergency services, 2018

\begin{tabular}{|c|c|c|c|c|}
\hline Author(s), Title & $\begin{array}{c}\text { Year/ } \\
\text { Country }\end{array}$ & Journal/Book & Method & Strategy* \\
\hline $\begin{array}{l}\text { Hudon C, Chouinard } \\
\text { M-C, Lambert M, } \\
\text { Diadiou F, Bouliane D, } \\
\text { Beaudin J.(23) } \\
\text { Key factors of case } \\
\text { management } \\
\text { interventions for } \\
\text { frequent users of } \\
\text { healthcare services: } \\
\text { a thematic analysis } \\
\text { review. }\end{array}$ & $\begin{array}{c}2017 \\
\text { Canada }\end{array}$ & $\begin{array}{l}\text { British Medical } \\
\text { Journal Open. }\end{array}$ & $\begin{array}{c}\text { Thematic } \\
\text { analysis } \\
\text { review }\end{array}$ & $1-5$ \\
\hline $\begin{array}{l}\text { Grover CA, Crawford } \\
\text { E, Close RJ. } \\
\text { The efficacy of } \\
\text { case management } \\
\text { on emergency } \\
\text { department frequent } \\
\text { users: an eight-year } \\
\text { observational study. }\end{array}$ & $\begin{array}{l}2016 \\
\text { United } \\
\text { States }\end{array}$ & $\begin{array}{l}\text { The Journal } \\
\text { of Emergency } \\
\text { Medicine }\end{array}$ & $\begin{array}{c}\text { Observational } \\
\text { study }\end{array}$ & $1-5$ \\
\hline
\end{tabular}

\begin{tabular}{|c|c|c|c|c|}
\hline Author(s), Title & $\begin{array}{l}\text { Year/ } \\
\text { Country }\end{array}$ & Journal/Book & Method & Strategy* \\
\hline $\begin{array}{l}\text { Edgren G, Anderson } \\
\text { J, Dolk A, Torgerson } \\
\text { J, Nyberg S, Skau T, } \\
\text { et al.(33) } \\
\text { A case management } \\
\text { intervention targeted } \\
\text { to reduce healthcare } \\
\text { consumption for } \\
\text { frequent Emergency } \\
\text { Department visitors: } \\
\text { results from an } \\
\text { adaptive randomized } \\
\text { trial. }\end{array}$ & $\begin{array}{c}2016 \\
\text { Sweden }\end{array}$ & $\begin{array}{l}\text { European } \\
\text { Journal of } \\
\text { Emergency } \\
\text { Medicine }\end{array}$ & \begin{tabular}{|} 
Randomized \\
controlled \\
clinical trial
\end{tabular} & $1-3,5$ \\
\hline $\begin{array}{l}\text { Bodenmann P, } \\
\text { Velonaki V-S, Griffin } \\
\text { JL, Baggio S, Iglesias } \\
\text { K, Moschetti K, et al. }{ }^{(32)} \\
\text { Case management } \\
\text { may reduce } \\
\text { emergency } \\
\text { department frequent } \\
\text { use in a universal } \\
\text { health coverage } \\
\text { system: a randomized } \\
\text { controlled trial. }\end{array}$ & $\begin{array}{c}2017 \\
\text { Switzerland }\end{array}$ & $\begin{array}{l}\text { Journal of } \\
\text { General } \\
\text { Internal } \\
\text { Medicine }\end{array}$ & \begin{tabular}{|} 
Randomized \\
controlled \\
clinical trial
\end{tabular} & $1-5$ \\
\hline $\begin{array}{l}\text { Soril } \sqcup \text {, Leggett } \\
\text { LE, Lorenzetti DL, } \\
\text { Noseworthy TW, } \\
\text { Clement FM..(29) } \\
\text { Reducing } \\
\text { frequent visits to } \\
\text { the emergency } \\
\text { department: a } \\
\text { systematic review of } \\
\text { interventions. }\end{array}$ & $\begin{array}{l}2015 \\
\text { Canada }\end{array}$ & Plos one & $\begin{array}{l}\text { Systematic } \\
\text { review }\end{array}$ & 1,2 \\
\hline $\begin{array}{l}\text { McCarty RL, Zarn J, } \\
\text { Fenn R, Collins RD. } \text {. }^{(30)} \\
\text { Frequent ED utilizers: } \\
\text { A case management } \\
\text { program to address } \\
\text { patient needs. }\end{array}$ & $\begin{array}{l}2015 \\
\text { United } \\
\text { States }\end{array}$ & $\begin{array}{c}\text { Nursing } \\
\text { management }\end{array}$ & $\begin{array}{c}\text { Before-and- } \\
\text { after quasi- } \\
\text { experimental } \\
\text { study }\end{array}$ & $1-4$ \\
\hline $\begin{array}{l}\text { Walsh K, Z. }{ }^{(31)} \\
\text { Emergency } \\
\text { Department Case } \\
\text { Management: the } \\
\text { compendium of best } \\
\text { practices }\end{array}$ & $\begin{array}{l}2014 \\
\text { United } \\
\text { States }\end{array}$ & \begin{tabular}{|c|} 
Emergency \\
Department \\
Case \\
Management: \\
the \\
compendium \\
of best \\
practices
\end{tabular} & - & 2 \\
\hline $\begin{array}{l}\text { Kumar GS, Klein } R^{(6)} \\
\text { Effectiveness of } \\
\text { case management } \\
\text { strategies in } \\
\text { reducing emergency } \\
\text { department visits in } \\
\text { frequent user patient } \\
\text { populations: a } \\
\text { systematic review. }\end{array}$ & $\begin{array}{l}2013 \\
\text { United } \\
\text { States }\end{array}$ & $\begin{array}{c}\text { The Journal } \\
\text { of Emergency } \\
\text { Medicine }\end{array}$ & $\begin{array}{l}\text { Systematic } \\
\text { review }\end{array}$ & $2-5$ \\
\hline $\begin{array}{l}\text { Reinius P, Johansson } \\
\text { M, Fjellner A, Werr J, } \\
\text { Öhlén G, Edgren G. }{ }^{(39)} \\
\text { A telephone-based } \\
\text { case-management } \\
\text { intervention } \\
\text { reduces healthcare } \\
\text { utilization for } \\
\text { frequent emergency } \\
\text { department visitors. }\end{array}$ & $\begin{array}{l}2013 \\
\text { Sweden }\end{array}$ & $\begin{array}{l}\text { European } \\
\text { Journal of } \\
\text { Emergency } \\
\text { Medicine }\end{array}$ & \begin{tabular}{|} 
Randomized \\
controlled \\
clinical trial
\end{tabular} & $1-3,5$ \\
\hline
\end{tabular}

To be continued 
Chart 3

\begin{tabular}{|c|c|c|c|c|}
\hline Author(s), Title & $\begin{array}{c}\text { Year/ } \\
\text { Country }\end{array}$ & Journal/Book & Method & Strategy* \\
\hline $\begin{array}{l}\text { Pillow MT, Doctor S, } \\
\text { Brown S, Carter K, } \\
\text { Mulliken } \mathrm{R}^{(42)} \\
\text { An emergency } \\
\text { department- } \\
\text { initiated, web-based, } \\
\text { multidisciplinary } \\
\text { approach to } \\
\text { decreasing } \\
\text { emergency } \\
\text { department visits } \\
\text { by the top frequent } \\
\text { visitors using patient } \\
\text { care plans. }\end{array}$ & $\begin{array}{l}2013 \\
\text { United } \\
\text { States }\end{array}$ & $\begin{array}{c}\text { The Journal } \\
\text { of Emergency } \\
\text { Medicine }\end{array}$ & $\begin{array}{c}\text { Retrospective } \\
\text { cohort study }\end{array}$ & $1,2,4$ \\
\hline $\begin{array}{l}\text { Rinke ML, Dietrich E, } \\
\text { KodeckT, Westcoat } \\
\mathrm{K}^{(41)} \\
\text { Operation care: } \\
\text { a pilot case } \\
\text { management } \\
\text { intervention for } \\
\text { frequent emergency } \\
\text { medical system users. }\end{array}$ & $\begin{array}{l}2012 \\
\text { United } \\
\text { States }\end{array}$ & $\begin{array}{c}\text { The American } \\
\text { Journal of } \\
\text { Emergency } \\
\text { Medicine }\end{array}$ & $\begin{array}{c}\text { Before-and- } \\
\text { after quasi- } \\
\text { experimental } \\
\text { study }\end{array}$ & $2-5$ \\
\hline $\begin{array}{l}\text { Althaus F, Paroz } \\
\text { S, Hugli O, Ghali } \\
\text { WA, Daeppen } \\
\text { J-B, Peytremann- } \\
\text { Bridevaux I, et al. }{ }^{(20)} \\
\text { Effectiveness of } \\
\text { interventions } \\
\text { targeting frequent } \\
\text { users of emergency } \\
\text { departments: a } \\
\text { systematic review. }\end{array}$ & $\begin{array}{c}2011 \\
\text { Canada }\end{array}$ & $\begin{array}{c}\text { Annals of } \\
\text { Emergency of } \\
\text { Medicine }\end{array}$ & $\begin{array}{c}\text { Systematic } \\
\text { review }\end{array}$ & 2,4 \\
\hline $\begin{array}{l}\text { Grover CA, Close RJ, } \\
\text { Villarreal K, Goldman } \\
\text { LM. }^{(4)} \\
\text { Emergency } \\
\text { department } \\
\text { frequent user: pilot } \\
\text { study of intensive } \\
\text { case management } \\
\text { to reduce visits } \\
\text { and computed } \\
\text { tomography. }\end{array}$ & $\begin{array}{l}2010 \\
\text { United } \\
\text { States }\end{array}$ & $\begin{array}{l}\text { The Western } \\
\text { Journal of } \\
\text { Emergency } \\
\text { Medicine }\end{array}$ & $\mid \begin{array}{c}\text { Retrospective } \\
\text { observational } \\
\text { study }\end{array}$ & $1-5$ \\
\hline $\begin{array}{l}\text { Skinner J, Carter L, } \\
\text { Haxton C. }{ }^{(12)} \text { Case } \\
\text { management } \\
\text { of patients who } \\
\text { frequently present to } \\
\text { a Scottish emergency } \\
\text { department. }\end{array}$ & $\begin{array}{c}2009 \\
\text { United } \\
\text { Kingdom }\end{array}$ & $\begin{array}{c}\text { Emergency } \\
\text { Medicine } \\
\text { Journal }\end{array}$ & $\begin{array}{c}\text { Prospective } \\
\text { observational } \\
\text { study }\end{array}$ & $1,2,4$ \\
\hline $\begin{array}{l}\text { Shumway M, } \\
\text { Boccellari A, O'Brien } \\
\text { K, Okin RL. }{ }^{(11)} \\
\text { Cost-effectiveness } \\
\text { of clinical case } \\
\text { management } \\
\text { for ED frequent } \\
\text { users: results of a } \\
\text { randomized trial. }\end{array}$ & $\begin{array}{l}2008 \\
\text { United } \\
\text { States }\end{array}$ & $\begin{array}{l}\text { The American } \\
\text { Journal of } \\
\text { Emergency } \\
\text { Medicine }\end{array}$ & $\begin{array}{c}\text { Randomized } \\
\text { controlled } \\
\text { clinical trial }\end{array}$ & $1,2,5$ \\
\hline
\end{tabular}

Chart

\begin{tabular}{|c|c|c|c|c|}
\hline Author(s), Title & $\begin{array}{c}\text { Year/ } \\
\text { Country }\end{array}$ & Journal/Book & Method & Strategy* \\
\hline $\begin{array}{l}\text { Phillips GA, Brophy } \\
\text { DS, Weiland TJ, } \\
\text { Chenhall AJ, Dent } \\
\text { AW. }{ }^{(8)} \\
\text { The effect of } \\
\text { multidisciplinary } \\
\text { case management } \\
\text { on selected } \\
\text { outcomes for } \\
\text { frequent attenders } \\
\text { at an emergency } \\
\text { department. }\end{array}$ & $\begin{array}{c}2006 \\
\text { Australia }\end{array}$ & $\begin{array}{l}\text { The Medical } \\
\text { Journal of } \\
\text { Australia }\end{array}$ & $\begin{array}{l}\text { Retrospective } \\
\text { cohort study }\end{array}$ & $1,2,4$ \\
\hline $\begin{array}{l}\text { Lee K-H, Davenport } \\
\mathrm{L} \text {.(40) } \\
\text { Can case } \\
\text { management } \\
\text { interventions } \\
\text { reduce the number } \\
\text { of emergency } \\
\text { department visits by } \\
\text { frequent users? }\end{array}$ & $\begin{array}{l}2006 \\
\text { United } \\
\text { States }\end{array}$ & $\begin{array}{c}\text { The Health } \\
\text { Care } \\
\text { Manager }\end{array}$ & $\begin{array}{l}\text { Before-and- } \\
\text { after study }\end{array}$ & $1-5$ \\
\hline $\begin{array}{l}\text { Walsh KT, Moran P, } \\
\text { Greenwood C. }{ }^{(45)} \\
\text { A successful } \\
\text { emergency } \\
\text { department case } \\
\text { management } \\
\text { practice model. }\end{array}$ & $\begin{array}{l}2003 \\
\text { United } \\
\text { States }\end{array}$ & Case Manager & - & $1,2,5$ \\
\hline $\begin{array}{l}\text { Okin RL, Boccellari A, } \\
\text { Azocar F, Shumway } \\
\text { M, O'Brien K, Gelb A, } \\
\text { et al. }{ }^{(7)} \\
\text { The effects of clinical } \\
\text { case management } \\
\text { on hospital service } \\
\text { use among ED } \\
\text { frequent users. }\end{array}$ & $\begin{array}{l}2000 \\
\text { United } \\
\text { States }\end{array}$ & $\begin{array}{l}\text { The American } \\
\text { Journal of } \\
\text { Emergency } \\
\text { Medicine }\end{array}$ & $\begin{array}{c}\text { Prospective } \\
\text { study }\end{array}$ & $1,2,4,5$ \\
\hline $\begin{array}{l}\text { Bristow DP, Herrick } \\
\text { CA. }{ }^{(44)} \\
\text { Emergency } \\
\text { department case } \\
\text { management: the } \\
\text { dyad team of nurse } \\
\text { case manager } \\
\text { and social worker } \\
\text { improve discharge } \\
\text { planning and patient } \\
\text { and staff satisfaction } \\
\text { while decreasing } \\
\text { inappropriate } \\
\text { admissions and costs: } \\
\text { a literature review. }\end{array}$ & $\begin{array}{l}2002 \\
\text { United } \\
\text { States }\end{array}$ & \begin{tabular}{|l|} 
Lippincotts \\
Case \\
Management
\end{tabular} & $\begin{array}{l}\text { Literature } \\
\text { review }\end{array}$ & $1,4,5$ \\
\hline $\begin{array}{l}\text { Pope D, Fernandes } \\
\text { CM, Bouthillette F, } \\
\text { Etherington J. }{ }^{(9)} \\
\text { Frequent users of } \\
\text { the emergency } \\
\text { department: a } \\
\text { program to improve } \\
\text { care and reduce } \\
\text { visits. }\end{array}$ & $\begin{array}{l}2000 \\
\text { Canada }\end{array}$ & $\begin{array}{l}\text { Canadian } \\
\text { Medical } \\
\text { Association } \\
\text { Journal }\end{array}$ & $\begin{array}{l}\text { Before-and- } \\
\text { after study }\end{array}$ & $1,2,4,5$ \\
\hline $\begin{array}{l}\text { Walsh KM. }{ }^{(46)} \\
\text { ED case managers: } \\
\text { One large teaching } \\
\text { hospital's experience. }\end{array}$ & $\begin{array}{l}1999 \\
\text { United } \\
\text { States }\end{array}$ & $\begin{array}{l}\text { Journal of } \\
\text { Emergency } \\
\text { Nursing }\end{array}$ & $\begin{array}{c}\text { Experience } \\
\text { report }\end{array}$ & $1,3,4,5$ \\
\hline
\end{tabular}


Chart 3 (concluded)

\begin{tabular}{|c|c|c|c|c|}
\hline Author(s), Title & $\begin{array}{c}\text { Year/ } \\
\text { Country }\end{array}$ & Journal/Book & Method & Strategy* \\
\hline $\begin{array}{l}\text { Brewer BB, Jackson } \\
\text { L.(43) } \\
\text { A case management } \\
\text { model for the } \\
\text { emergency } \\
\text { department. }\end{array}$ & 1997 & $\begin{array}{l}\text { Journal of } \\
\text { Emergency } \\
\text { Nursing }\end{array}$ & $\begin{array}{c}\text { Experience } \\
\text { report }\end{array}$ & $1-5$ \\
\hline
\end{tabular}

Note: *Strategy employed: 1. Screening/identification and assessment; 2 . Individualized care plan; 3. Support and communication in transitional care; 4. Coordination of care through a multidisciplinary team; 5 . Monitoring and follow-up of patients.

The studies showed that the most frequent users are patients with complex needs related to vulnerability (people with psychiatric problems, substance abuse, especially alcohol and drugs, chronic clinical conditions (cardiovascular, neurological and pulmonary) and, to psychosocial stressors (social isolation, lack of health insurance, homeless people, poverty, lack of community resources and housing).

Moreover, it was highlighted in some studies that the frequent, disproportionate and inappropriate use of emergency services increases the demand, costs, and damages the adequate quality and safety of care in these units ${ }^{(4-9,11-12,20,23,29-30,32-33,40,42)}$.

The researchers presented different configurations for the team responsible for case management in emergency services. Models centered on the role of nurses ${ }^{(4-5,21,30,32-33,39-40,42-43,44,46)}$ and contemporary models were identified, in an expanded and multidisciplinary perspective, composed of physicians, nutritionists, nurses, occupational therapists, physiotherapists, and social workers ${ }^{(7-9,12,45)}$.

The case managers actions in emergency services were performing the screening, and assessing the psychosocial needs of patients and families $(33,39,41,44,46)$; evaluate the discharged patients' needs and who are at high risk for readmission ${ }^{(46)}$; identifying the motivation of individuals to seek assistance in emergency departments ${ }^{(4,30)}$ and, the barriers to receive care in an outpatient setting ${ }^{(30,43)}$.
Other roles of case managers include facilitating decisionmaking and coordination of clinical care ${ }^{(8,23)}$; promoting diversified and safe discharge ${ }^{(8)}$, helping teams to develop individualized care plans ${ }^{(4,8,23,33,39,41,45-46)}$. They are responsible for promoting educational actions for self-management of care ${ }^{(8,23,33,41)}$; coordinating care follow-up by informing patients about care level options, and thereby contributing to reducing the misuse of emergency services due to organizational care limitations ${ }^{(8,30,44)}$.

Regarding the strategies used for case management, a central concern was identified with care optimization to prevent or reduce the need for new access to emergency departments by frequent users. In this context, case managers play an essential role in implementing the continuum of hospital and community care services, which includes clinical assessment, coordination, and communication with other service providers(32).

In the studies analyzed, strategies focused on coordinating and integrating patients to return to the community prevailed, by monitoring the results of both the care team and the case manager $(4,7,32,40,44)$. Activities identified as useful were primarily a comprehensive and extensive clinical assessment; technological improvement, such as electronic health records, to establish effective communication between the different levels of health care; and notification of case managers about potential patients to be admitted to the program ${ }^{(7,42)}$.

These activities improve the experience of patient care in emergency services; facilitate the decision-making of the multidisciplinary team for safe transfer of responsibility for care to other levels of health care and the family context; optimize communication among health professionals, patients, and family members; favor the definition of the most appropriate level of care to reduce the length of stay and avoid frequent use of emergency services; reduce costs of care; and, consequently, promote safety and quality ${ }^{(39,41,45)}$. The main strategies implemented for case management are synthesized in Chart 4.

Chart 4- Synthesis of strategies implemented for case management in emergency services, 2018

\begin{tabular}{|c|c|}
\hline STRATEGY & SYNTHESIS OF STRATEGIES IMPLEMENTED \\
\hline $\begin{array}{l}\text { Risk } \\
\text { stratification } \\
\text { screening/ } \\
\text { identification }\end{array}$ & 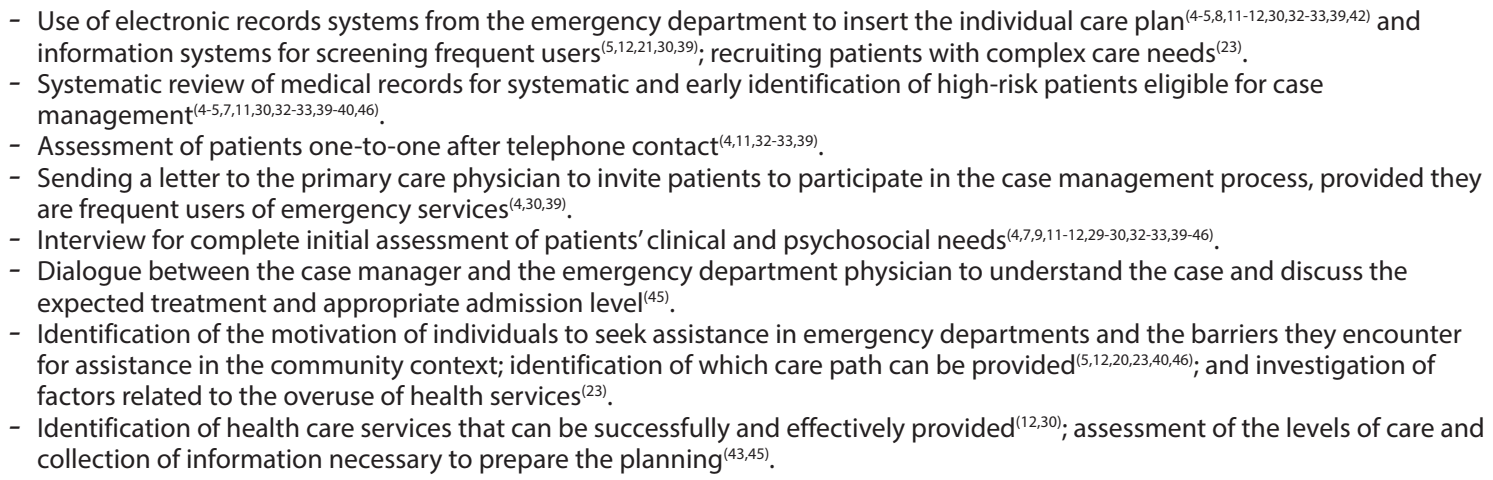 \\
\hline $\begin{array}{l}\text { Care } \\
\text { management } \\
\text { plan }\end{array}$ & $\begin{array}{l}\text { - Individualized care plan developed by the case manager together with the multidisciplinary team to coordinate the services } \\
\text { for patients }(4-9,12,23,30,32-33,39-42) \text {; understanding of patients' clinical needs; providing recommendations for the care plan; avoiding } \\
\text { inappropriate hospitalizations and reducing the number of visits to emergency departments }{ }^{(20,23,29,43)} \text {. } \\
\text { - It should involve best practices related to planning the transition of patients with complex psychosocial needs by the social } \\
\text { worker; simple transfer planning performed by emergency department case managers, and discharge planning after patient } \\
\text { admission to the emergency department performed by a home case manager and social worker }{ }^{(31)} \text {. } \\
\text { - Directed to the clinical and social needs of patients and families }{ }^{(4,11-12,30,32-33,39-41)} \text {. } \\
\text { - Focus on establishing therapeutic goals and objectives that promote self-management of health and counseling in search of } \\
\text { solutions to psychosocial problems and definition of the best follow-up of care in other levels of health care }{ }^{(8,30)} \text {. } \\
\text { - Engagement of the entire care team in creating a comprehensive care plan, with interventions and continuous reassessments } \\
\text { of patients' problems } s^{(4-5,7,23,32-33,39-42)} \text {. }\end{array}$ \\
\hline
\end{tabular}




\begin{tabular}{|c|c|}
\hline STRATEGY & SYNTHESIS OF STRATEGIES IMPLEMENTED \\
\hline $\begin{array}{l}\text { Care } \\
\text { management } \\
\text { plan }\end{array}$ & $\begin{array}{l}\text { - Invitation and active involvement of patients in the review of their case (self-management); participation in creating their } \\
\text { individualized care plan and in the search for solutions to their problems }{ }^{(4,9,11,30,33)} \text {; and dialogue with the team and family } \\
\text { about the need for referrals, care plans and goals to be achieved }{ }^{(45)} \text {. } \\
\text { - Conducting complex transition planning to coordinate clinical care in emergency departments }{ }^{(9,46)} \text {; discharge plan }{ }^{(41)} ; \text { creating } \\
\text { a comprehensive after discharge care plan, including coordination of care in insurance, transportation, housing and meeting } \\
\text { clinical, and psychosocial need }\left(^{(4,6-7,11,20,23,29-30,32,43,45)} \text {. }\right. \\
\text { - Promotion of actions involving health education, empowerment in decision-making, and encouraging self-management of } \\
\text { care and patient participation in developing their care plan }{ }^{(20,23,45)} \text {. } \\
\text { - The care plan should be updated, revised, and shared considering the needs of patients and future risk of hospital admission, } \\
\text { according to stratification }{ }^{(12,23,41)} \text {. } \\
\text { 1. High risk (care plan reviewed every three months, intensive case management and advocacy); } \\
\text { 2. Medium risk (care plan revised in } 6 \text { months and telephone contact to monitor and implement the care plan and address } \\
\text { emerging problems); } \\
\text { 3. Low risk (care plan revised in } 12 \text { months). }\end{array}$ \\
\hline $\begin{array}{l}\text { Post-transition } \\
\text { support and } \\
\text { communication }\end{array}$ & $\begin{array}{l}\text { - Patient education and guidance on the proper use of the health system and clinical and social services available in the } \\
\text { community }{ }^{(6,23,30,32-33,39-41,46)} \text {; helping patients find solutions to their problems }{ }^{(5,43)} \text {; } \\
\text { - Patient guidance regarding self-management of care, offering care options, and helping you to make appropriate choices }{ }^{(32-33)} \text {; } \\
\text { patient counseling on risky behaviors (e.g., substance abuse) and clinical service use }{ }^{(23,30,32,43)} \text {. } \\
\text { - Communication with the entire team and with different providers and levels of } \text { care }^{(32,41,43)} \text {; liaison with other community } \\
\text { agencies } s^{(7,22,40) ;} \text { communication with other levels of care }{ }^{(33,39,41)} \text {; informing the primary health care physician about scheduled } \\
\text { appointments and the need for follow-up }{ }^{(32)} \text {. }\end{array}$ \\
\hline $\begin{array}{l}\text { Care } \\
\text { coordination }\end{array}$ & $\begin{array}{l}\text { - The multidisciplinary work includes physicians, nurses, social workers }{ }^{(4-5,7-9,12,32,40-44)}, \text { primary care professionals, nutritionist, } \\
\text { occupational therapist, physiotherapist, among others }{ }^{(8,46)} \text {; } \\
\text { - Collaborative work with the multidisciplinary team to support case management }{ }^{(23,40)} \text { and develop recommendations } \\
\text { regarding the use of this service and treatments that should be provided in this } \operatorname{context}^{(4)} \text {; } \\
\text { - Multidisciplinary case conference to discuss } \operatorname{cases}^{(5-6,9,12,20,23,30,41-42)} \text {; }\end{array}$ \\
\hline $\begin{array}{l}\text { Follow-up, } \\
\text { assessment, } \\
\text { and periodic } \\
\text { reassessment } \\
\text { of patients' } \\
\text { needs and } \\
\text { progress }\end{array}$ & 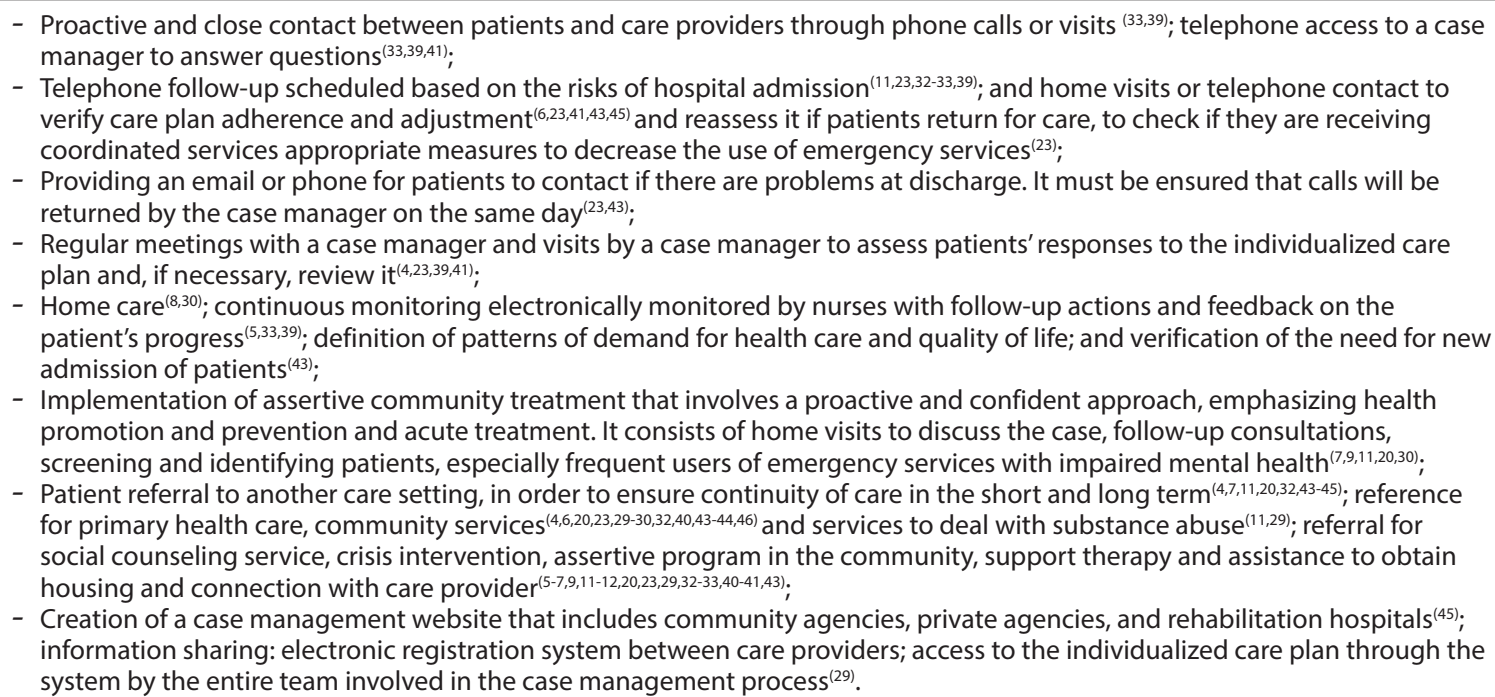 \\
\hline
\end{tabular}

The strategies adopted for managing the cases included: screening and assessment of patients ${ }^{(5,8,11-12,30,32-33,39-40)}$; development of an individualized care plan ${ }^{(4-5,7-8,12,32-33,39-42)}$; care coordination through a multidisciplinary performance ${ }^{(4-5,7-8,12,32)}$; support for the transition process through patient education actions ${ }^{(22,32,40-41)}$; communication ${ }^{(7,30,32,40-41)}$; monitoring, follow-up, and assessment $^{(33,39,41)}$ for periodic verification of their needs and progress.

Case management begins with screening and assessment in emergency departments when case managers review the medical records and electronic records to identify frequent service users at high risk of relapse and with complex care needs ${ }^{(32-33)}$. Then, telephone or letter contact is made with patients eligible to receive case management, inviting them to participate in the program $^{(4,11,32-33,39)}$. If accepted, they attend a one-to-one interview with the case manager, to collect information about their clinical and psychosocial needs as well as to identify the reason that led them to seek emergency care and the barriers identified by them for primary care assistance ${ }^{(4,11-12,30,32-33,39-41)}$. This information enables identifying the appropriate level of care for patients to ensure timely access and continuity of care ${ }^{(12,30)}$.

Emphasis on developing individualized care plans was placed in most of the studies analyzed ${ }^{(5-6,8,11-12,30,32-33,39)}$. Care plans aim to coordinate the services needed for patients for both hospitalization and outpatient treatment; prevent inappropriate admissions; improve discharge plans; reduce costs; ensure patient satisfaction and refer to appropriate locations ${ }^{(40)}$.

There is an incentive to involve and actively participate in developing a care plan, as they are factors that favor decisionmaking and contribute to identifying appropriate solutions to problems ${ }^{(8,30)}$. Thus, it is possible to allow patient improvement concerning the care they need, and the means of achieving $\mathrm{it}^{(4,11,30)}$ are evidenced.

Another significant aspect concerns implementing electronic records systems in emergency departments, since they allow to 
identify frequent service users and create an individualized care plan. In this way, the multidisciplinary team will have access to the information of these patients and will be able to adapt the plan, if necessary ${ }^{(4-5,12,39,41-42)}$.

The study conducted by Pillow et al. ${ }^{(42)}$ showed that implementing a program for electronic screening through alert icons visualized in the electronic registration system of emergency departments helps identify frequent users with complex care needs. In such cases, the team must communicate the fact to the case manager so that the case management process can be triggered. A professional case manager then places a notice on a board in the emergency department to alert the medical and nursing staff about the treatment of patients enrolled in the program ${ }^{(4)}$.

Patient education is a necessary approach throughout the case management process. Case managers act as advisors and educators ${ }^{(23,40)}$, both concerning care self-management and on the services available at different levels ${ }^{(6,30,32)}$. Moreover, they provide patient guidance to properly use the health system $(20,32,41,46)$, providing care options, and helping them make the most appropriate choices ${ }^{(32,44)}$.

Communication among professionals, provision of resources in the community, access to primary care physicians, quality of care and reduction of costs, visits, and inappropriate admissions to emergency departments are expected and reported results in most interventions ${ }^{(5,21,41)}$.

In emergency services, there were, among frequent users, people in situations of vulnerability due to mental health problems and alcohol and drug abuse. For this population, emergency service case managers maintain direct communication with primary care professionals; and together, they participate in planning strategies to ensure the follow-up, assessment, and periodic reassessment of patients' needs and their progress in primary care ${ }^{(7-8,11,30)}$.

One of these strategies involves assertive community outreach treatment, performed by professionals with training in social assistance, nursing, and psychiatry. The aim is to provide intensive support and guided by their needs so that patients return to the community and do not need new hospitalizations or seek emergency services unnecessarily ${ }^{(7-8,11,30)}$.

Multidisciplinary teams must act in an interconnected manner under the leadership of case managers, whose central role is to promote coordination between clinical and social service providers, emergency services, outpatient care, and home care $^{(4-6,8,111-12,20,23,29,30,32,40-42,44,46)}$.

Another key action involves patient monitoring and follow-up. The studies that addressed this strategy highlighted case management through telephone contact and home visits, facilitating communication with other health professionals through case managers, and monitoring after the implementation of the managed care plan ${ }^{(33,39)}$. These studies indicated that this follow-up improves service to users, contributes to reducing the number of visits to emergency departments, days, and costs of hospitalizations and, consequently, favors health system use.

In this sense, studies have shown that case management is a model of care coordination that involves patients and allows them to be referred to the level most appropriate to their clinical and psychosocial condition. It occurs through the assessment of available support services and identification of barriers found for timely access, to meet the real needs of patients and promote safe discharge $\mathrm{e}^{(6,8,20,23,33,40,44)}$.

\section{DISCUSSION}

This scoping review mapped the scientific evidence related to case management strategies in the transition of care for adults and older people with complex needs in emergency services over the past 21 years. Current case management models involve the conception of people-centered care, with the perspective of guaranteeing people effective continuity of health care. It requires a multidisciplinary health assessment system formed by a set of logical steps and a process of interaction between health care networks to guarantee an appropriate transition of patient care throughout the health system ${ }^{(3,27)}$.

Most of the mapped and synthesized studies showed that the case management strategies implemented in an emergency, for users with complex care needs, have been effective in reducing service use. Furthermore, according to studies, these actions guarantee coordination and continuity of care for other settings, especially for primary care $\mathrm{c}^{(5,12,30,33,39,41-42)}$.

This model has been used to integrate services around patients' individual needs through the coordination of care $\mathrm{e}^{(7,30,32,40-41)}$. It can be implemented through using information technologies, such as electronic health records systems, to identify patients who need to be enrolled in this type of program ${ }^{(5,30,42)}$.

In emergency services, this process has the central objective of promoting the ideal transition of patients to guarantee continuity of care and better adapt the use of these services ${ }^{(7,11,32)}$. There is evidence that this model contributes to patients obtaining the necessary care in the health system $(4,7,12,27,40)$.

Case management responds to the complex needs of patients and aims to promote self-management of care and improve the integration of this population with health services ${ }^{(23)}$. Case management has taken on a central role in terms of coordinating high complexity care in emergency services, especially for frequent users who have complex clinical and psychosocial ne eds $^{(8-9,12,20,23,29,32,40-41)}$. In some cases, such strategies also include the relatives of these patients $s^{(9,23,45)}$.

It is perceived that case management, when effectively implemented, promotes the connection of patients with primary care, which is fundamental to avoid fragmentation of care. However, for this to be genuinely contemplated, it is necessary to have a case manager who works within the emergency department and establishes communication with the outpatient network about the essential care for patients, ensuring continuity and avoiding recurrences in the service ${ }^{(4-6,9,20,29,23,32-33)}$.

Case management is an intervention that favors the monitoring of these people through screening, care, and follow-up planning for continuous monitoring of patients' progress and patterns of demand for health care, quality of life, and feedback regarding patients' responses to implemented care plans ${ }^{(5,33,39)}$.

Screening emerges as a central element and involves an approach with embracement, identification, and accurate assessment of users and their families, not only to solve their immediate problem, but mainly, to promote adequate regulation to other levels of care. Moreover, this step is vital to ensure 
continuity of information for other health professionals and, above all, to promote safe and useful user navigation in the health system $^{(5,12,23,32,42)}$. Screening patients includes the assessment of their clinical and psychosocial needs, intending to identify early risks of admission and readmission in emergency services. These people are monitored until stability or until they can seek care in the appropriate setting ${ }^{(39)}$.

However, for this plan to be successfully implemented, one of the essential strategies for case management intervention in emergency services, in addition to the presence of a professional case manager and the involvement of patients in creating their care plan, consists of developing and implementing an electronic registration system ${ }^{(23,30,32-33,39,42)}$. This strategy allows establishing timely communication and promotes the support and participation of patients, families, the multidisciplinary team, and healthcare team in the construction, adherence, and adequacy of the plan, whenever necessary.

As a strategy for linking users, the studies highlighted the importance of effective communication between the case manager and other professionals involved in the development process as well as the review of individualized care plans in primary care. These factors promoted patient engagement and partnership between primary care professionals and those of the services for which, generally, these users will be referred to follow this plan ${ }^{(4-5,7-9,11-12,40)}$.

Some studies have highlighted the role of nurses and social workers in leading case management implementation in emergency services ${ }^{(20,23,44-45)}$. The partnership with social work was emphasized as well as the importance of psychosocial interventions and planning of complex transitions from acute care to outpatient care.

The researchers also highlighted the nurses 'competence to carry out an expanded clinical assessment of patients' needs, their knowledge about the management of organizational resources, and interpersonal, leadership and communication skills to work with other team members. Nurses were recognized as a link between the different levels of health care and as responsible for promoting continuity of care, reducing fragmentation, and favoring more positive results ${ }^{(20,23,44-45)}$.

Case management in emergency services requires skills to serve clients comprehensively and holistically concerning clinical, psychosocial, behavioral, and spiritual needs; encourage self-care, and increase the involvement of individuals and caregivers in decision-making ${ }^{(10,28)}$.

Another essential action provided by case management is the possibility of patient follow-up and monitoring. To that end, strategies such as telephone contact can be adopted to clarify the patients' doubts about the care plan. Case managers carry out home visits to assess responses to the care plan and, if necessary, promote adjustments ${ }^{(39,41)}$.

The researchers also highlighted the comprehensive care actions related to health counseling and education with a focus on self-management and guidelines for dealing with psychosocial issues. Many highlighted the integrated performance of the multidisciplinary team and the central role of nursing and social work in this process ${ }^{(4-9,11-12,20,23,29-30,32-33,40,42)}$.

To briefly summarise, most of the case management strategies were multimodal and included strategies to promote health education ${ }^{(30)}$; screening focusing on the patients' biopsychosocial needs ${ }^{(33,39)}$; development of an individualized care plan ${ }^{(12,30,33)}$; social service support ${ }^{(33)}$; and coordination of care within the health service system ${ }^{(8,12,32,39-42)}$.

Such strategies are centrally focused on minimizing fragmentation of care within the health system and help patients navigate this system, as they favor access to appropriate resources available in the different care spaces and facilitate user engagement and development ${ }^{(28)}$. The central objective is to guarantee the best results using standard guidelines, working together with the interdisciplinary team, improving safety and customer satisfaction, favoring adherence to the care plan for costumers, including adherence to medication ${ }^{(27,31-32)}$.

It is a process that aims to ensure the right care, in the right place and at the right time, avoiding fragmented care ${ }^{(27-28)}$, which facilitates promoting effective care and quality results for patients. For this strategy to be effective, collaboration, cooperation, and mutual effort between different health care providers are essential. Besides, the coordination aims to organize care so that it is accessible whenever necessary. Another crucial aspect is communication, as case managers must work with several people to ensure that patients receive care ${ }^{(27)}$.

To sum up, employing case management strategies in transitional care in emergency services contributes to planning discharge and transferring responsibility from emergency services to other levels of health care. Home context prevents inappropriate admissions, reduces service usage and costs, and improves patient and team satisfaction. Besides, case managers become a link between patients and community resources. They advise patients on the importance of follow-up with primary care professionals; improve clinical management across the continuum of care; and promote the effective defense of patients so that they have ensured continuity of care ${ }^{(44)}$.

\section{Study limitation}

There are some related scoping review limitations, mainly because this type of literature review provides breadth rather than depth in analysis of the identified evidence ${ }^{(35-36)}$. However, it was possible to map and synthesize the strategies used for case management in transitional care in emergency services, which will allow guiding clinical practice and future research in this field.

\section{Contributions to nursing, health, and public policies}

In general, the results reaffirmed the need for emergency services to have a professional case manager and specific multidisciplinary team to survey, select and coordinate frequent users in this sector, especially those with complex care needs.

Another aspect that deserves to be considered is the inclusion of the theme in the curricular matrix of training courses in health, for the knowledge of the role and the importance of professional case managers and case management strategies in the transition of care of these patients throughout the continuum of care. It is noteworthy the lack of studies on case management in developing countries, including Brazil, which demands special attention from the academic and scientific community for this theme. There 
was little emphasis on studies on family participation during the case management process.

\section{FINAL CONSIDERATIONS}

This scoping review presented a global perspective on the 23 studies that addressed the strategies used for case management in the transitional care of patients with complex needs in emergency services.

In conclusion, it was identified that screening with risk assessment; individualized and progressive care planning; and coordination of care through establishing effective communication among multidisciplinary teams in different care contexts were fundamental to the favorable outcomes of the strategies implemented. Furthermore, they favor identifying possible paths for emergency service qualification. Strategies were also highlighted to promote support for the transition process through health education actions and the establishment of communication between the different levels of health care and monitoring, follow-up and assessment of patients to verify the progress of their health care needs.
Employing case management responded to the complex needs of vulnerable costumer through a structured approach that promoted support for self-management and favored integration of patients with health services. In addition, developing an individualized care plan to meet the clinical and social needs of patients is capable of promoting adequate use of emergency resources and services.

In general, the results reaffirm the need for emergency services to have a professional case manager and specific multidisciplinary team to coordinate the care of frequent users; and to identify the motivations of frequent search and the barriers of access to other levels of health care.

Using case management strategies favors coordination and continuity of care in the health service network; and contributes to patients being properly informed about the services available to meet their needs and the appropriate time to use emergency services. Such aspects are necessary to build innovative and interactive ways to promote the ideal transitional care of patients with complex care needs, which transcend the limits of traditional care in emergency services.

\section{REFERENCES}

1. Coleman EA. Falling through the cracks: challenges and opportunities for improving transitional care for persons with continuous complex care needs. J Am Geriatr Soc. 2003;51(4):549-55. doi: 10.1046/j.1532-5415.2003.51185.x

2. Coleman EA, Boult C. Improving the quality of transitional care for persons with complex care needs. J Am Geriatr Soc. 2003;51(4):556-7. doi:10.1046/j.1532-5415.2003.51186.x

3. Bodenheimer T, Berry-Millett R. Care management of patients with complex health care needs. Synth Proj Res Synth Rep. 2009 [cited 2017 Set 18];1(6). Available from: https://www.ncbi.nlm.nih.gov/pubmed/22052205.

4. Grover CA, Close RJ, Villarreal K, Goldman LM. Emergency department frequent user: pilot study of intensive case management to reduce visits and computed tomography. West J Emerg Med[Internet]. 2010 [cited 2017 Sep 18];11(4):336-43. Available from: https://www.ncbi. nlm.nih.gov/pubmed/21079705

5. Grover CA, Crawford E, Close RJ. The efficacy of case management on emergency department frequent users: an eight-year observational study. J Emerg Med. 2016;51(5):595-604. doi: 10.1016/j.jemermed.2016.06.002

6. Kumar GS, Klein R. Effectiveness of case management strategies in reducing emergency department visits in frequent user patient populations: a systematic review. J Emerg Med. 2013;44(3):717-29. doi: 10.1016/j.jemermed.2012.08.035

7. Okin RL, Boccellari A, Azocar F, Shumway M, O'brien K, Gelb A, et al. The effects of clinical case management on hospital service use among ED frequent users. Am J Emerg Med. 2000;18(5):603-8. doi: 10.1053/ajem.2000.9292

8. Phillips GA, Brophy DS, Weiland TJ, Chenhall AJ, Dent AW. The effect of multidisciplinary case management on selected outcomes for frequent attenders at an emergency department. Med J Aust. 2006;184(12):602-6. doi: 10.5694/j.1326-5377.2006.tb00412.x

9. Pope D, Fernandes $C M$, Bouthillette F, Etherington J. Frequent users of the emergency department: a program to improve care and reduce visits. Cmaj [Internet]. 2000 [cited 2018 Sep 12];162(7):1017-20. Available from: https://www.ncbi.nlm.nih.gov/pubmed/10763402

10. Roberts RM, Dalton KL, Evans JV, Wilson CL. A service model of short-term case management for elderly people at risk of hospital admission. Aust Health Rev. 2007;31(2):173-83. doi: 10.1071/ah070173

11. Shumway M, Boccellari A, O'brien K, Okin RL. Cost-effectiveness of clinical case management for ED frequent users: results of a randomized trial. Am J Emerg Med. 2008;26(2):155-64. doi: 10.1016/j.ajem.2007.04.021

12. Skinner J, Carter L, Haxton C. Case management of patients who frequently present to a Scottish emergency department. Emerg Med J. 2009;26(2):103-5. doi: 10.1136/emj.2008.063081

13. Kuluski K, Ho JW, Hans PK, Nelson ML. Community care for people with complex care needs: bridging the gap between health and social care. Int J Integr Care. 2017;17(4):2. doi: https://doi.org/10.5334/ijic.2944

14. Manning E, Gagnon M. The complex patient: a concept clarification. Nurs Health Sci. 2017;19(1):13-21. doi: 10.1111/nhs.12320

15. Naylor MD, Aiken LH, Kurtzman ET, Olds DM, Hirschman KB. The importance of transitional care in achieving health reform. Health Aff (Millwood). 2011;30(4):746-54. doi: 10.1377/hlthaff.2011.0041 
16. Burke RE, Kripalani S, VasilevskisEE, Schnipper JL. Moving beyond readmission penalties: creating an ideal process to improve transitional care. J Hosp Med. 2013;8(2):102-9. doi: 10.1002/jhm.1990

17. Snow V, Beck D, Budnitz T, Miller DC, Potter J, Wears RL, et al. Transitions of care consensus policy statement: American college of physicians, society of general internal medicine, society of hospital medicine, american geriatrics society, american college of emergency physicians, and society for academic emergency medici ne. J Hosp Med. 2009;4(6):364-70. doi: 10.1002/jhm.510

18. Atzema CL, Maclagan LC. The transition of care between emergency department and primary care: a scoping study. Acad Emerg Med. 2017;24(2):201-15. doi: 10.1111/acem.13125

19. Acosta AM, Da Silva Lima MAD. Características de usuários frequentes de serviços de urgência: revisão integrativa. Rev Eletrôn Enferm. 2013[cited 2017 May 15];15(2):564-73. Available from: https://www.fen.ufg.br/revista/v15/n2/pdf/v15n2a31.pdf

20. Althaus F, Paroz S, Hugli O, Ghali WA, Daeppen J-B, Peytremann-Bridevaux I, et al. Effectiveness of interventions targeting frequent users of emergency departments: a systematic review. Ann Emerg Med. 2011;58(1):41-52. e42. doi: 10.1016/j.annemergmed.2011.03.007

21. Brewster LR, Rudell LS, Lesser CS. Emergency room diversions: a symptom of hospitals under stress. Issue Brief Cent Stud Health Syst Change [Internet]. 2001 [cited 2017 May 15];(38):1-4. Available from: https://www.ncbi.nlm.nih.gov/pubmed/11603406

22. Freitas LFC, Moreira DA, Brito MJM. The continuity of care from the perspective of the being cared for. 2014;19(4):636-42. doi: 10.5380/ ce.v19i4.35993

23. Hudon C, Chouinard M-C, Lambert M, Diadiou F, Bouliane D, Beaudin J. Key factors of case management interventions for frequent users of healthcare services: a thematic analysis review. BMJ Open. 2017;7(10):e017762. doi: 10.1136/bmjopen-2017-017762

24. Hong CS, Siegel AL, Ferris TG. Caring for high-need, high-cost patients: what makes for a successful care management program. Issue Brief (Commonw Fund) [Internet]. 2014 [cited 2017 May 15];19(1):1-19. Available from: https://www.ncbi.nlm.nih.gov/pubmed/25115035

25. Kim Y-J, Soeken KL. A meta-analysis of the effect of hospital-based case management on hospital length-of-stay and readmission. Nurs Res [Internet]. 2005 [cited 2017 May 17];54(4):255-64. Available from: https://www.ncbi.nlm.nih.gov/pubmed/16027568

26. National Case Management Network (CA). Canadian standards of practice in case management. [Internet] Ottawa: National Case Management Network; 2009 [cited 2017 Mar 08]. [about 18 p.]. Available from: http://www.ncmn.ca/standards

27. Finkelman A. Professional nursing concepts: competencies for quality leadership. 4th ed. Burlington (MA): Jones \& Bartlett Learning; $2019.1294 \mathrm{p}$.

28. Tahan HM, Treiger TM. CMSA core curriculum for case management. 3rd ed. Philadelphia: Williams \& Wilkins. 2017. 738 p.

29. Soril LJ, Leggett LE, Lorenzetti DL, Noseworthy TW, Clement FM. Reducing frequent visits to the emergency department: a systematic review of interventions. PloS One. 2015;10(4):e0123660. doi: 10.1371/journal.pone.0123660

30. McCarty RL, Zarn J, Fenn R, Collins RD. Frequent ED utilizers: A case management program to address patient needs. Nurs Manage. 2015;46(9):24-31. doi: 10.1097/01.NUMA.0000470771.17731.3d

31. Walsh K, Z. Emergency Department Case Management: the compendium of best practices [Internet] 2nd ed. Danvers (MA): HCPro; 2014 [cited 2018 Aug 21]. Available from: https://hcmarketplace.com/aitdownloadablefiles/download/aitfile/aitfile_id/1616.pdf

32. Bodenmann P, Velonaki V-S, Griffin JL, Baggio S, Iglesias K, Moschetti K, et al. Case management may reduce emergency department frequent use in a universal health coverage system: a randomized controlled trial. J Gen Intern Med [Internet]. 2017 [cited 2018 Nov 12];32(5):508-15. Available from: https://www.ncbi.nlm.nih.gov/pubmed/27400922

33. Edgren G, Anderson J, Dolk A, Torgerson J, Nyberg S, Skau T, et al. A case management intervention targeted to reduce healthcare consumption for frequent Emergency Department visitors: results from an adaptive randomized trial. Eur J Emerg Med. 2016;23(5):344-50. doi: 10.1097/mej.0000000000000280

34. Joo JY, Huber DL. Scoping Review of Nursing Case Management in the United States. Clin Nurs Res. 2018;27(8):1002-16. doi: $10.1177 / 1054773817717861$

35. Peters MDJ, Godfrey CM, Khalil H, McInerney P, Parker D, Soares CB. Guidance for conducting systematic scoping reviews. Int J Evid Based Healthc [Internet]. 2015 [cited 2018 Sep 21];13(3):141-6. Available from: https://www.ncbi.nlm.nih.gov/pubmed/26134548

36. Levac D, Colquhoun H, O'Brien KK. Scoping studies: advancing the methodology. Implement Sci [Internet]. 2010 [cited Dec 12];5(1):69. Available from: 10.1186/1748-5908-5-69

37. Tricco AC, Lillie E, Zarin W, O'Brien KK, Colquhoun H, Levac D, et al. PRISMA Extension for Scoping Reviews (PRISMA-ScR): checklist and explanation. Ann Intern Med. 2018[cited 2018 Aug 21];169(7):467-73. Available from: https://www.ncbi.nlm.nih.gov/pubmed/30178033

38. American Case Management Association. Standards of practice and scope of services for health care delivery system case management and transitions of care professionals [Internet] Little Rock; 2013 [cited 2018 Aug 21]. Available from: https://www.acmaweb.org/forms/ Case_Management_SoP_SoS.pdf.

39. Reinius $P$, Johansson $M$, Fjellner A, Werr J, Öhlén G, Edgren G. A telephone-based case-management intervention reduces healthcare utilization for frequent emergency department visitors. Eur J Emerg Med. 2013;20(5):327-34. doi: 10.1097/MEJ.0b013e328358bf5a

40. Lee K-H, Davenport L. Can case management interventions reduce the number of emergency department visits by frequent users? Health Care Manag (Frederick) [Internet]. 2006 [cited 2018 Sep 20];25(2):155-9. Available from: https://www.ncbi.nlm.nih.gov/pubmed/16699330

41. Rinke ML, Dietrich E, Kodeck T, Westcoat K. Operation care: a pilot case management intervention for frequent emergency medical system users. Am J Emerg Med. 2012;30(2):352-7 doi: 10.1016/j.ajem.2010.12.012 
42. Pillow MT, Doctor S, Brown S, Carter K, Mulliken R. An emergency department-initiated, web-based, multidisciplinary approach to decreasing emergency department visits by the top frequent visitors using patient care plans. J Emerg Med. 2013;44(4):853-60. doi: 10.1016/j.jemermed.2012.08.020

43. Brewer BB, Jackson L. A case management model for the emergency department. J Emerg Nurs. 1997;23(6):618-21. doi: 10.1016/ s0099-1767(97)90280-4

44. Bristow DP, Herrick CA. Emergency department case management: the dyad team of nurse case manager and social worker improve discharge planning and patient and staff satisfaction while decreasing inappropriate admissions and costs: a literature review. Lippincotts Case Manag. [Internet]. 2002 [cited 2018 May 2];7(6):243-51. Available from: https://www.ncbi.nlm.nih.gov/pubmed/12048342

45. Walsh KT, Moran P, Greenwood C. A successful emergency department case management practice model. Case Manager [Internet]. 2003[cited 2018 Sep 5];14(6):54-7. Available from: https://www.ncbi.nlm.nih.gov/pubmed/14618150

46. Walsh KM. ED case managers: one large teaching hospital's experience. J Emerg Nurs [Internet]. 1999 [cited 2018 Sep 5];25(1):17-20. Available from: https://www.ncbi.nlm.nih.gov/pubmed/9925673 